\title{
The transport system of standard road semi-trailers providing for their horizontal-skew transshipment
}

\section{System transportu standardowych naczep drogowych z poziomym, skośnym przeladunkiem naczep}

\begin{abstract}
The paper presents the concept of an innovative solution of a wagon for transportation of standard road semi-trailers in combined traffic. The concepts of a wagon itself and a rotation mechanism designed for horizontal-skew trailer transshipment to a wagon are presented. The solution may be an alternative to the French system Modalohr, the German CargoBeamer and the Swedish Flexiwaggon.
\end{abstract}

$W$ artykule zaprezentowano koncepcje innowacyjnego rozwiazania wagonu dla transportu standardowych naczep drogowych $w$ ruchu kombinowanym. Przedstawiono koncepcje wagonu oraz mechanizmu obrotu przeznaczonego do poziomego, skośnego przeładunku naczepy na wagon. Rozwiazanie może stanowić alternatywe dla francuskiego systemu Modalohr, niemieckiego CargoBeamer oraz szwedzkiego Flexiwaggon.

\section{Introduction}

The most common load unit in road freight transport is a semi-trailer. In intermodal transport the semi-trailers, just like containers and swap bodies, form an integrated cargo unit. Two types of trailers are distinguished, i.e. the universal and special ones. The universal units require no design changes. They are standard semi-trailers used in road transport, commonly available on the market. On the other hand, the special trailers are adapted according to the rail transport. Among them the units requiring only small structural changes (reinforcements) may be distinguished that enable proper transshipment, such as e.g. semitrailers designed for transport in pocket wagons. There exist also the units requiring more significant structural changes, which being located between the bogie supports make a part of the train, serve as the loadbearing structures and carry longitudinal forces arising in the train. An example of such a set is a bimodal system that meets the strength requirements of the UIC-597 Card.

As the solution of the new intermodal (combined) system presented in the paper is designed to transport the universal, unmodified road trailers, the most popular systems for transporting such trailers are presented below.

The German CargoBeamer system (Fig. 1) allows to transport standard semi-trailers. It requires specially prepared terminals and advanced design of railway wagons with a mobile platform. This solution

\section{Wstęp}

Najczęściej wykorzystywaną jednostką ładunkową $w$ towarowych przewozach drogowych są naczepy siodłowe. W transporcie intermodalnym naczepy podobnie jak kontenery i nadwozia wymienne stanowią zintegrowaną jednostkę ładunkową. Można tu wyróżnić dwa rodzaje naczep, uniwersalne oraz specjalne. Jednostki uniwersalne nie wymagaja jakichkolwiek zmian w konstrukcji, są to standardowe, szeroko dostępne naczepy na rynku używane w transporcie drogowym. Natomiast naczepy specjalne, są odpowiednio przystosowane do przewozu kolejowego. Wśród nich możemy wyróżnić jednostki, które wymagają niewielkich zmian (wzmocnień) w konstrukcji umożliwiających odpowiedni przeładunek, jak np. naczepy do przewozu w wagonach kieszeniowych. Występują też jednostki wymagające większych zmian w konstrukcji, które w składzie kolejowym między podparciami na wózkach stanowią strukturę nośną oraz przenoszą wzdłużne siły kolejowe. Przykładem takiego zespołu jest system bimodalny, spełniający wymagania wytrzymałościowe Karty UIC-597.

Ponieważ przedstawione $\mathrm{w}$ artykule rozwiązanie nowego systemu intermodalnego (czy kombinowanego) służy do przewozu uniwersalnych, niezmodyfikowanych naczep drogowych, poniżej dokonano prezentacji najbardziej popularnych systemów służących do przewozu takich naczep.

Niemiecki system CargoBeamer (rys. 1) umożliwia transport standardowych naczep siodłowych. 
consists in horizontal, transverse automatized handling of the semi-trailers. While unloading, the jacks built in the railway track lift the platform with the trailer to proper height, thus enabling insertion of horizontal conveyors. Afterwards, the lifts lower the platform to the journals of the conveyors, that move it perpendicularly to the track axis. One platform with a trailer may be loaded on the wagon simultaneously with unloading of another. The side walls of the wagons are lowered in order to allow to extend/retract the platform with the trailer, avoiding their excessive lifting. The trailer may be also vertically loaded, with the use of cranes or high-storage trucks with clamp grippers, so-called "reach stackers". This system is constantly improved, being in implementation and experimental stage.

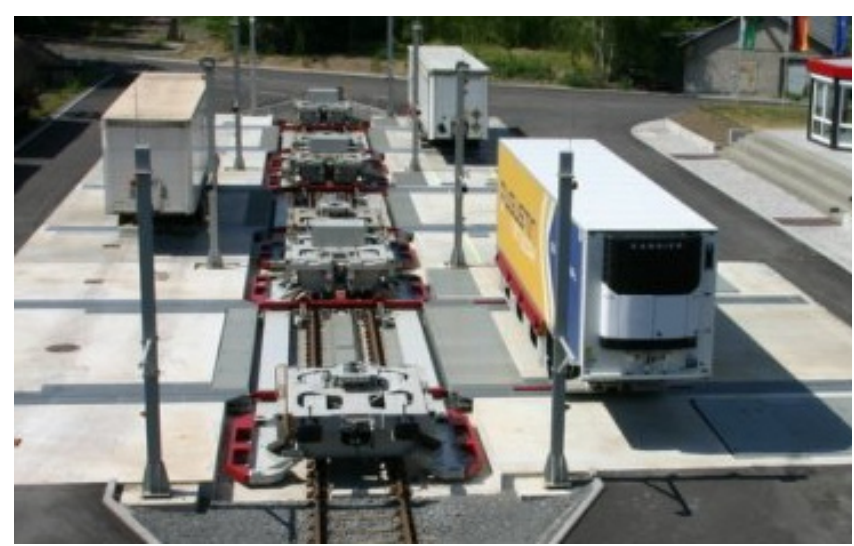

Rys.1. The CargoBeamer System - experimental transshipment point

Rys. 1. System CargoBeamer - doświadczalny plac przeładunkowy

In another system for transporting standard semi-trailers the well wagons are used. According to this technology a tractor introduces the semi-trailer into a so-called basket, that is then vertically loaded to the wagon. The semi-trailer requires no reinforcements and grips for clamp grippers. The basket provided with handles is an additional element, and the railway wagon is adjusted to locate it inside. Such a system may be used without additional investment in existing transshipment sites in the terminals designed for combined traffic. The semi-trailers are vertically loaded by means of cranes or high storage wagons using clamp grippers. It is a solution widely used in Poland and other European countries. An example of this technology is the NiKRASA system (Fig.2) (German "nicht kranbare sattelauflieger", i.e. the semi-trailers that cannot be lifted by a crane). This system is currently used in integrated road terminals Padborg, Verona, Bettembourg and Trieste. NiKRASA was funded by the Bavarian Ministry of Economy, Infrastructure, Transport and Technology and the Austrian Ministry of Transport, Innovation and Technology as a part of the innovation program for intermodal traffic.
Wymaga specjalnie przygotowanych terminali oraz zaawansowanej konstrukcji wagonów kolejowych $\mathrm{z}$ ruchomą platformą. W rozwiązaniu tym zastosowano poziomy, poprzeczny przeładunek, który odbywa się w sposób zautomatyzowany. Podczas wyładunku zabudowane $\mathrm{w}$ torze podnośniki unoszą platformę $\mathrm{z}$ naczepa na odpowiednią wysokość umożliwiająca wsunięcie przenośników poziomych. Następnie podnośniki opuszczają platformę w miejsce osadzenia na czopach przenośników, które przesuwają ją w kierunku prostopadłym do osi toru. Załadunek kolejnej platformy $z$ naczepą na wagon może odbywać się równocześnie z wyładunkiem innej. Boczne ściany wagonów są opuszczane aby umożliwić wysunięcie/wsunięcie platformy wraz z naczepa bez ich znacznego unoszenia. Przeładunek może odbywać się również w sposób pionowy przy użyciu suwnic lub wozów wysokiego składowania z chwytakami kleszczowymi tzw. ,reach stacker-y”. System ten jest na bieżąco ulepszany i znajduje się w fazie wdrożeniowej, eksperymentalnej.

Kolejnym systemem do przewożenia standardowych naczep jest wagon koszowy. W tej technologii naczepa samochodowa jest wprowadzana za pomoca ciągnika siodłowego do tzw. „kosza”, który następnie wstawiany jest do wnętrza wagonu poprzez wykorzystanie przeładunku pionowego. Naczepa nie wymaga wzmocnień i uchwytów dla chwytaków kleszczowych. Dodatkowym elementem jest platforma „kosz”, która posiada uchwyty a wagon kolejowy przystosowany jest do jej umiejscowienia wewnątrz. W tym systemie istniejące już miejsca przeładunkowe w terminalach dla ruchu łączonego (kombinowanego) można wykorzystywać bez dodatkowych inwestycji. Przeładunek pionowy odbywa się za pomocą suwnic lub wozów wysokiego składowania przy użyciu chwytaków kleszczowych. Jest to powszechnie używane rozwiązanie w Polsce oraz innych krajach europejskich. Przykładem tej technologii jest system NiKRASA (rys. 2) (niem. nicht kranbare sattelauflieger, czyli naczepy siodłowe, których nie można podnosić dźwigiem). System ten obecnie wykorzystywany jest w połaczonych terminalach drogowych Padborg, Werona, Bettembourg i Triest. NiKRASA została sfinansowana przez bawarskie Ministerstwo Gospodarki, Infrastruktury, Transportu i Technologii oraz austriackie Ministerstwo Transportu, Innowacji i Technologii w ramach programu innowacji dla ruchu intermodalnego.

Rozwiązanie francuskie o nazwie Modalohr (rys. 3) jest przegubowym wagonem $z$ dwoma obrotowymi platformami. W systemie tym można przewozić naczepy siodłowe $w$ transporcie nietowarzyszącym a także kompletne zestawy drogowe (ciagnik siodłowy oraz naczepa siodłowa). Odłączając zestaw drogowy, naczepa jest ładowana na jedną platformę, natomiast na druga ciagnik siodłowy ładowany jest wraz z ciągnikiem od następnego zestawu drogowego. Przeładu- 


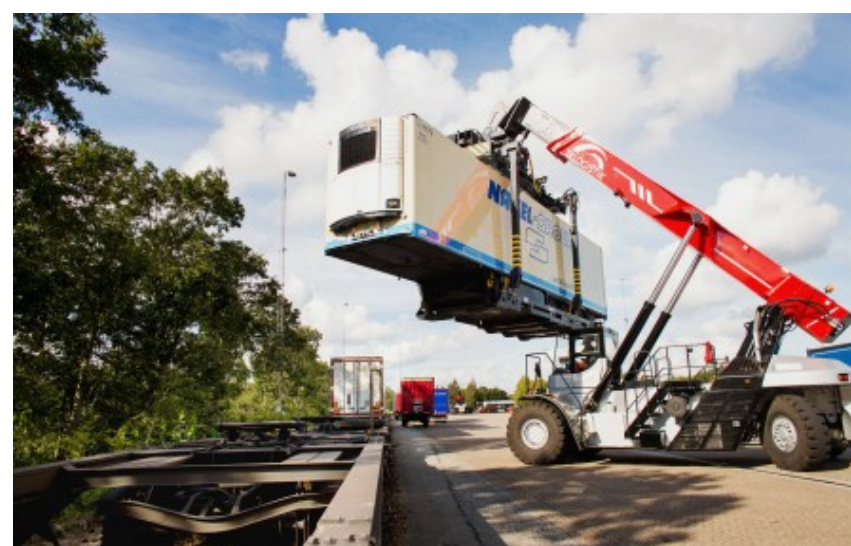

Fig. 2. Platform with semi-trailer during loading to the NiKRASA well wagon

Rys. 2. Platforma z naczepą podczas załadunku na wagon koszowy systemu NiKRASA

The French solution called Modalohr (Fig. 3) is an articulated wagon with two swivel platforms. The system allows for unaccompanied transport of semitrailers as well as complete road sets (composed of a tractor and semi-trailer). Three platforms hold two road sets, since two semi-trailers are loaded on two platforms while the third one holds both tractor units. The trans-shipment is carried out horizontally. Wagon reloading systems located on the terminal consist of two units. The first one, located between the rails, serves for lifting the platform and bears its weight. The other, provided with motorized rollers, causes rotation of the platform. At present there are 2 such pilot lines. This solution is implemented on a $1050 \mathrm{~km}$ line operated by the Lorry-rail company, connecting the Bettembourg and Le Boulou (near Perpignan) terminals. In case of the line connecting Aition with Orbassano near Turin, operated by Ferroviaria Alpina, the train sets run on a distance of $175 \mathrm{~km}$.

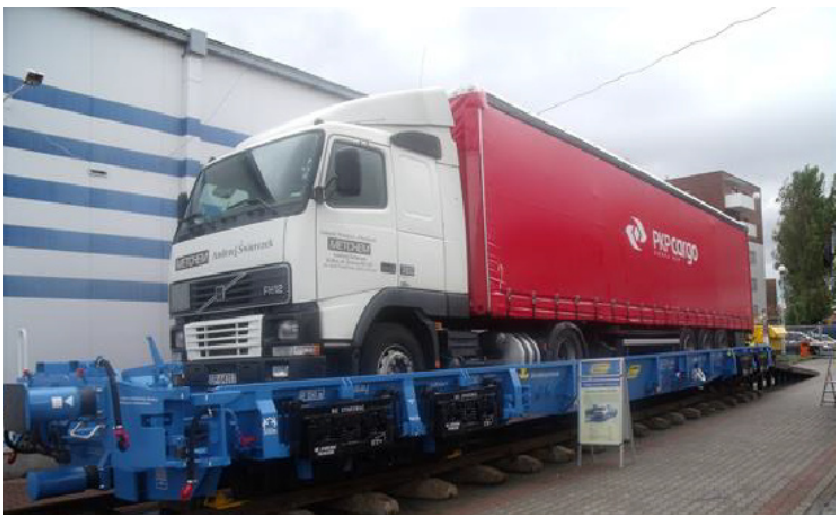

Fig. 4. The gutter wagon designed by RVI „TABOR”

Rys. 4. Wagon rynnowy konstrukcji IPS „TABOR”

A system of gutter wagons (Fig.4) known as "moving road" (German: Ro-La or Rollende Landstrasse, English Rolling Motorway) is designed for transporting standard road semi-trailers with semitrailer tractors as well as containers. In order to load the trailers on the wagon, the terminals are equipped nek odbywa się w technologii poziomej. Układy przeładunku wagonów znajdujące się na terminalu składają się z dwóch zespołów. Pierwszy, układ unoszenia umieszczony pomiędzy szynami zapewnia przejęcie ciężaru platformy. Drugi, układ wyposażony w napędzane rolki, które powodują obrót platformy. Obecnie uruchomione sa 2 linie pilotażowe. Rozwiązanie to funkcjonuje na linii liczącej $1050 \mathrm{~km}$, obsługiwanej przez firmę Lorry-rail łączącą terminal w Bettembourg $\mathrm{z}$ terminalem w Le Boulou koło Perpignan. Na linii łączącej Aition z Orbassano koło Turynu, obsługiwanej przez firmę Ferroviaria Alpina, składy kurują na dystansie $175 \mathrm{~km}$.

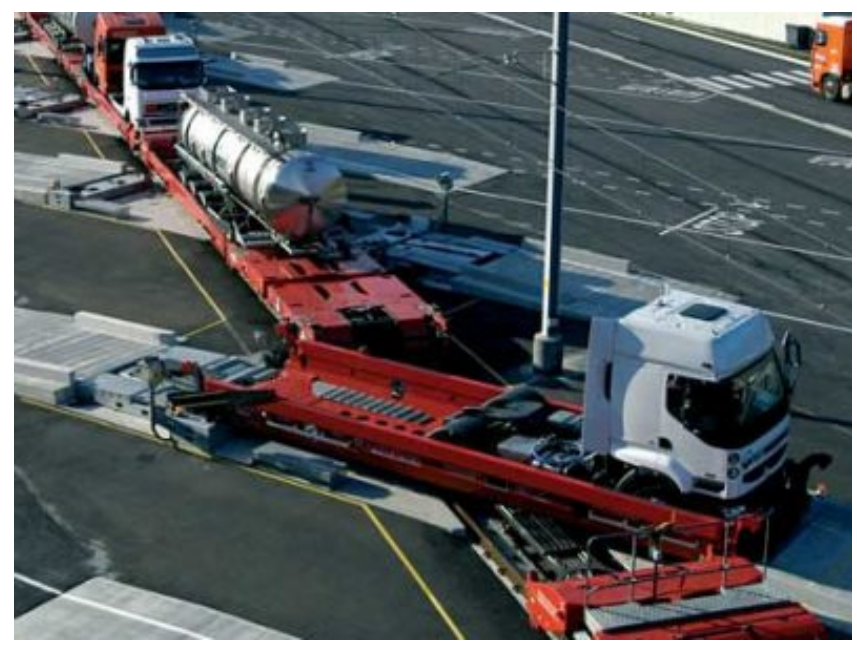

Fig. 3. Modalohr system during loading

Rys. 3. System Modalohr w trakcie załadunku

System wagonów rynnowych (rys. 4) używany pod nazwą „ruchoma droga” (niem. Ro-La czyli Rollende Landstrasse, ang. rolling motorway) jest przystosowany do transportu standardowych naczep drogowych wraz z ciagnikami siodłowymi a także kontenerów. Do załadunku wagonu terminale są wyposażone w podjazdy klinowe, po których ciagniki z naczepami wjeżdżają z poziomu terminala na poziom podłogi wagonów. Podczas procesu za- i wyładunku jest możliwość pracy pod siecią trakcyjna. Stosowane są składy pociagów złożone z krótkospiętych wagonów, które na końcach są wyposażone w typowe urządzenia pociagowo-zderzne. Przewozy Ro-La są dość powszechnie stosowane na kolejach zachodnioeuropejskich. Ich funkcjonowanie jest możliwe dzięki subwencjom rządowym, tworzonym $\mathrm{w}$ ramach promocji transportu kombinowanego.

Szwedzkie rozwiązanie o nazwie Flexiwaggon (rys. 5) może transportować zestawy drogowe o długości do 17,5 metrów, wadze 50 ton i wysokości 4 metrów, może służyć również do transportu autobusów, kontenerów, nadwozi wymiennych. Wagon jest zaawansowaną konstrukcją, której platforma załadunkowa może zostać otworzona $\mathrm{z}$ obu stron. Rozwiązanie to umożliwia opuszczenie i załadunek pojazdów wzdłuż trasy niezależnie od innych pojazdów przewożonych tym składem. Jest to dużą zaletą w stosunku 
with ramp wedges, allowing the tractor with a trailer to move from the terminal to wagon level. The loading and unloading may be carried out under the overhead line. The train sets composed of tightly coupled wagons are used, provided at the ends with typical buffing and draw gears. Ro-La traffic is commonly used on West European railways. It operates thanks to government subsidies funded as part of the promotion of combined transport.

The Swedish solution Flexiwaggon (Fig. 5) can transport the road units up to 17.5 meters long, 4 meters high and weighing up to 50 tons. It may be used also for transporting buses, containers or swap bodies. The wagon is an advanced structure whose loading platform can be opened from both sides. The solution allows to lower and load vehicles along the route, independently of other vehicles transported by the vehicle. This is a big advantage as compared to the gutter vehicles where such an operation is impossible.

The solutions of road trailer transport systems presented in the article have a common feature - i.e. universality of the integrated load unit. Nevertheless, the system of well wagons differs in the way of the loading procedure from the other systems. The trailers are vertically loaded on the well wagons, while in case of the other systems the loading is horizontal. Most modern systems have been designed with a view to reduce the reloading time, providing the option of simultaneous horizontal loading. The gutter wagon and Flexiwaggon systems also stand out in comparison with other technologies - they may transport only entire road vehicles. Transportation of the semi-trailer alone is impossible. In case of the Modalohr system a tractor unit may be additionally transported. do pojazdów rynnowych gdzie takiej operacji nie można wykonać.

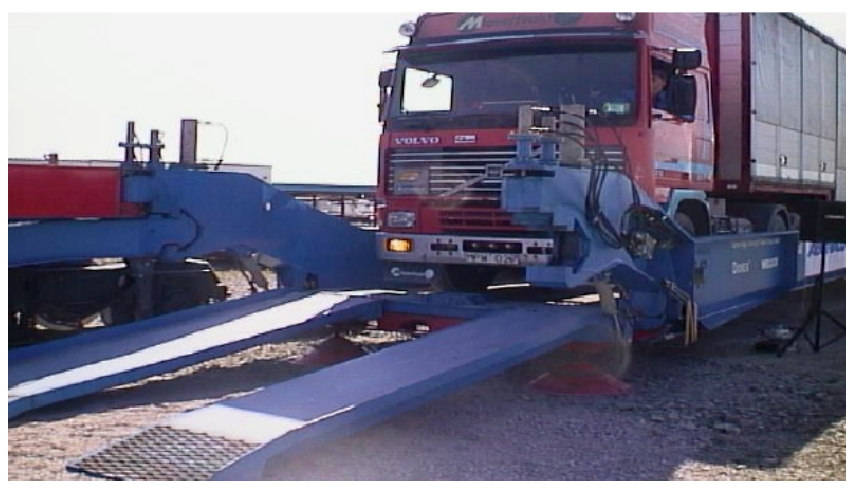

Fig. 5. Tilted Flexiwaggon platform during unloading

Rys. 5. Odchylona platforma wagonu Flexiwaggon podczas wyładunku

Przedstawione $\mathrm{w}$ artykule rozwiązania systemów do transportu naczep drogowych mają wspólną cechę - uniwersalność zintegrowanej jednostki ładunkowej. Natomiast system wagonów koszowych różni się sposobem załadunku naczep (załadunek pionowy, ang. vertical loading) od pozostałych systemów (załadunek poziomy, ang. horizontal loading). Większość nowoczesnych systemów została zaprojektowana $\mathrm{z}$ myślą o skróceniu czasu przeładunku i zastosowano $\mathrm{w}$ nich możliwość jednoczesnego załadunku poziomego. Systemy wagon rynnowy oraz Flexiwaggon również wyróżniają się na tle pozostałych technologii, można w nich przewozić wyłącznie całkowite pojazdy drogowe, nie ma możliwości przewozu samej naczepy, natomiast $\mathrm{w}$ systemie Modalohr można dodatkowo przewozić ciagnik siodłowy.

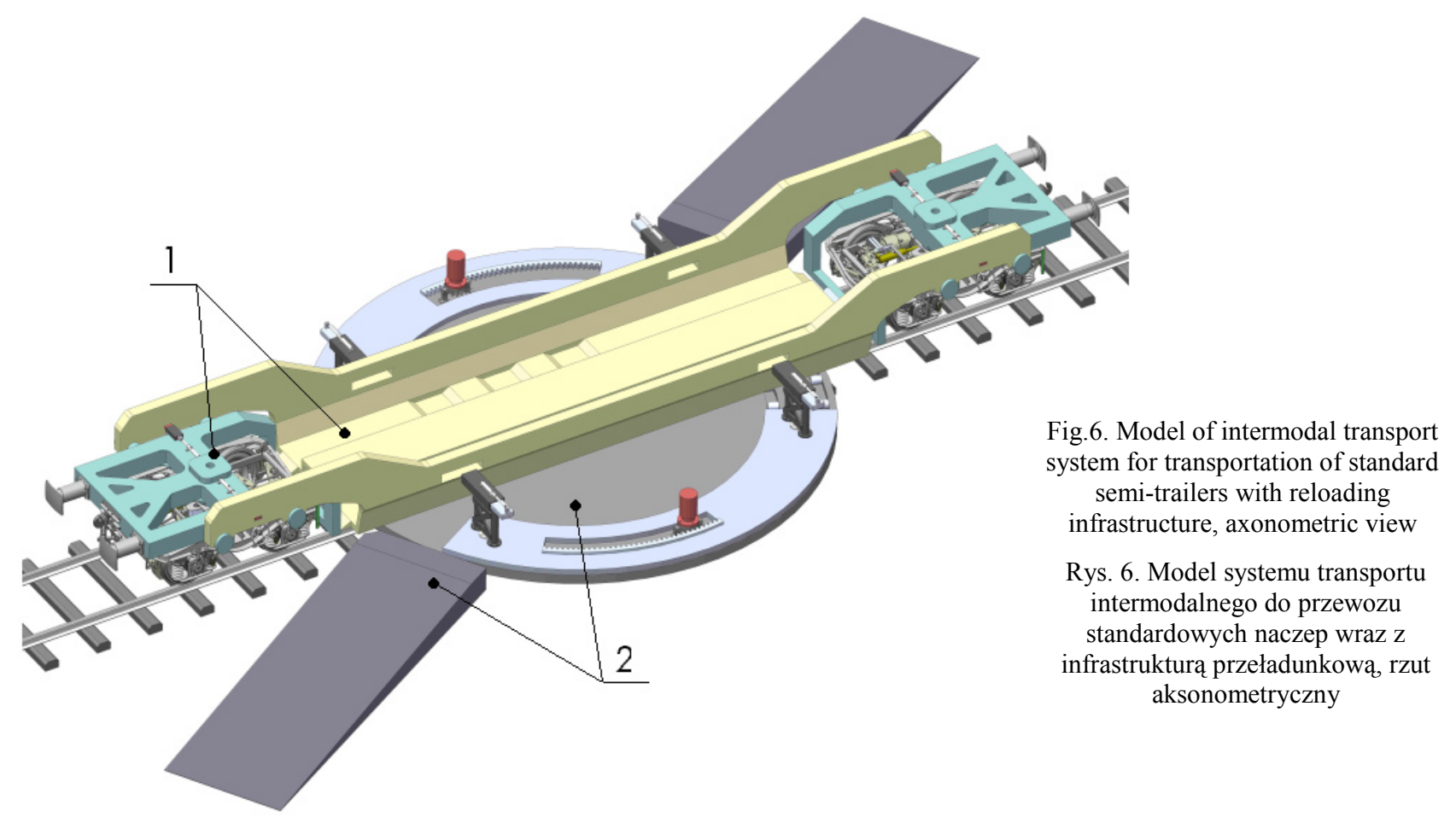




\section{Structure of the system}

An innovative intermodal transport system for carrying standard road semi-trailers is shown in Fig. 6. Comprehensivsness of the system is ensured by the wagon (item 1) together with the reloading infrastructure (item 2).

\subsection{Load-bearing structure of the system}

The wagon (Fig. 7a, b) has two identical twoaxle bogies (item 3 ). The advantage of the system is that they are standard Y 25 bogies designed for freight wagons with wheel thread diameter $\phi 920$. The overbogie frames (item 4) permanently connected by a longitudinal beam (item 5) and a removable platform (basket) (item 6) are located above.

The basket is designed for placing the semi-trailer (item 7). On the sides of the over-bogie frames, two properly spaced flange journals (item 8 ) are provided on each longitudinal beam, in order to support the platform. Along the axis of symmetry of the bogies, the sliding housing located devices (item 9) are placed on the over-bogie frames, serving to lock the basket to the wagon. They are driven by pneumatic actuators. A saddle (item 10) is placed on the central transverse beam of the frame, in order to support the front of the trailer at the kingpin. Standard buffing and draw gears (item 11) are installed on the wagon frame ends.
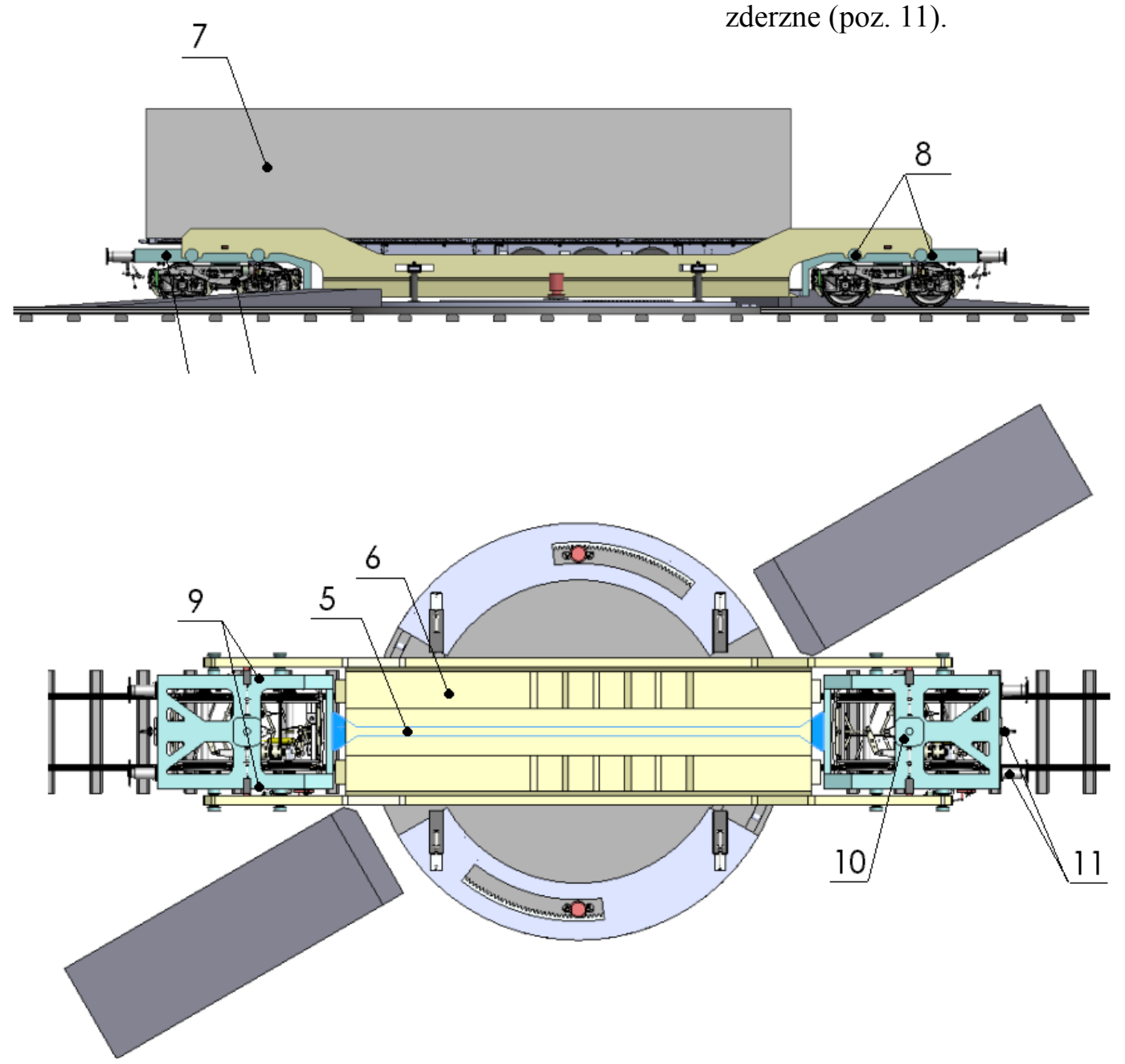

\section{Struktura systemu}

Innowacyjny system transportu intermodalnego do przewozu standardowych naczep drogowych przedstawia rysunek 6 . Kompleksowość systemu stanowi wagon (poz. 1) wraz z infrastruktura przeładunkową (poz. 2).

\subsection{Struktura nośna systemu}

Wagon (rys. 7a,b) składa się z dwóch identycznych wózków dwuosiowych (poz. 3). Walorem syste$\mathrm{mu}$ jest to, że są to wózki standardowe do wagonów towarowych typu Y25 o średnicy okręgu tocznego kół $\phi$ 920. Powyżej znajdują się ramy nadwózkowe (poz. 4), połączone na stałe belką podłużną (poz. 5) oraz odejmowalną platformą (koszem) (poz. 6).

Kosz stanowi miejsce, w którym ulokowana jest naczepa siodłowa (poz. 7). Po bocznych stronach ram nadwózkowych na belkach podłużnych przewidziano po dwa odpowiednio rozstawione czopy kołnierzowe (poz. 8) służące do oparcia platformy. Wzdłuż osi symetrii wózków również na ramach nadwózkowych znajdują się prowadzone $\mathrm{w}$ obudowie suwliwe urządzenia ryglujące kosz na wagonie (poz. 9). Urządzenia te są napędzane siłownikami pneumatycznymi. Na centralnej belce poprzecznej ramy umiejscowiono siodło (poz. 10) do oparcia przodu naczepy w miejscu sworznia królewskiego. Na czołownicach wagonu zabudowano standardowe urządzenia pociagowozderzne (poz. 11).

Fig.7a. Model of intermodal transport system for transportation of standard semi-trailers - side view

Rys.7a. Model systemu transportu intermodalnego do przewozu standardowych naczep, widok $\mathrm{z}$ boku wagonu

Fig.7b. Model of intermodal transport system for transportation of standard semi-trailers - top view, without the semi-trailer

Rys. 7b. Model systemu transportu intermodalnego do przewozu standardowych naczep, $\mathrm{z}$ góry wagonu, bez naczepy siodłowej 
The wagon platform (Fig.8) is a welded structure composed of side walls and floor. At the ends of the side walls (arms) the radial notches (item 12) are located, designed in order to support the platform on the vehicle's journals. Rectangular openings (item 13) designed for the snap locks are also placed there. Rectangular holes (item 14) reinforced from the top, intended for lifting and rotating the platform, are placed in the side walls in proper distance from the vertical symmetry plane. In the side parts of the floor, there are three hollows (item 15) for the semi-trailer wheels, while in the middle part, from the bottom, a properly shaped channel (item 16) is placed for the longitudinal frame fastening beam passing through the bottom. At the ends of the floor side parts the ramp wedges are provided (item 17).

Fig. 9 shows a variant of the basket mounting method in which the over-bogie frame is provided with single flanged journal on each side of the frame (item 18). The journals are placed in the transverse symmetry plane of the bogie. In result the locking devices (item 19) are located at appropriate distance from the pivot fixing plane towards the wagon centre.
Platforma wagonu (rys. 8) jest konstrukcją spawaną złożoną z ścian bocznych oraz podłogi. Na końcach ścian bocznych (ramionach) przewidziano promieniowe wycięcia (poz. 12) pod oparcie platformy na czopach wagonu oraz prostokatne otwory (poz. 13) pod zamki ryglujące. W ścianach bocznych w odpowiedniej odległości od płaszczyzny pionowej symetrii wykonano wzmocnione $\mathrm{w}$ górnej części prostokątne otwory (poz. 14), które są wykorzystywane do unoszenia i obrotu platformy. W częściach bocznych podłogi wykonano po trzy zagłębienia (poz. 15) pod koła naczepy a w części środkowej od strony dolnej wykonano odpowiednio ukształtowany kanał (poz. 16) dla przechodzącej dołem belki podłużnej spinającej ramy. $\mathrm{Na}$ końcach bocznych części podłogi przewidziano kliny najazdowe (poz. 17).

Na rysunku 9 pokazano odmianę sposobu zamocowania kosza gdzie ramę nadwózkową wyposażono w jeden czop kołnierzowy po każdej stronie ramy (poz. 18). Czopy umieszczone są w poprzecznej płaszczyźnie symetrii wózka, w wyniku tego urządzenia ryglujące (poz. 19) umieszczono w odpowiedniej odległości od płaszczyzny mocowania czopów w kierunku do środka wagonu.

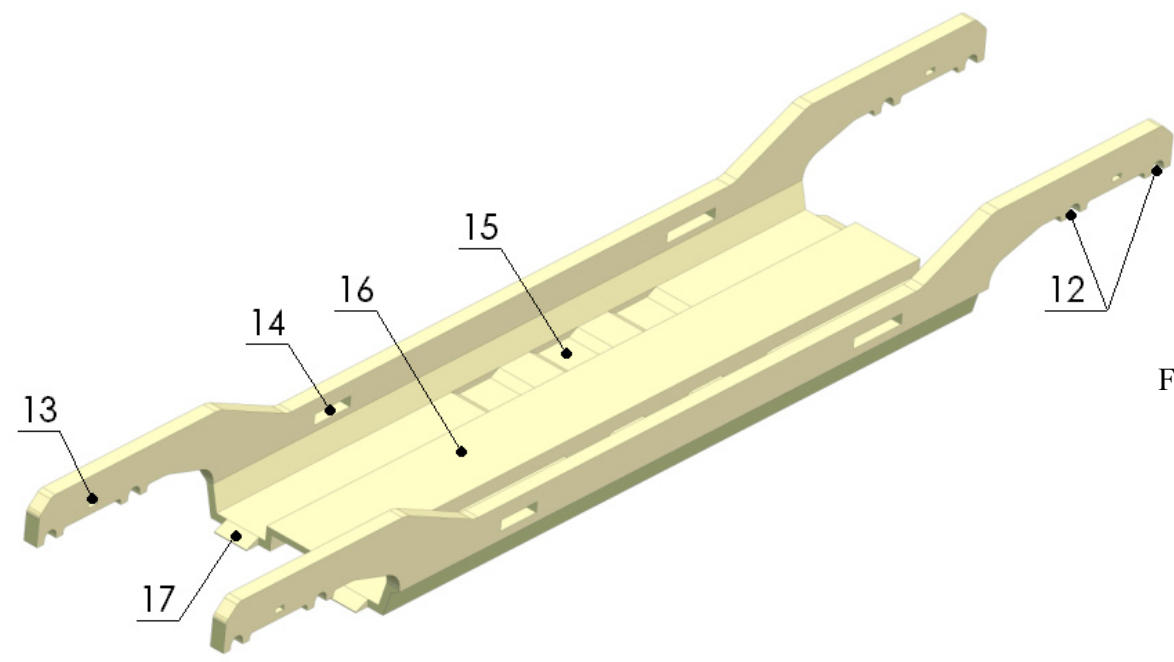

Fig.8. Model of the wagon platform (basket)

Rys. 8. Model platformy (kosza) wagonu

Fig.9. The wagon in the version equipped with a single journal on each frame side

Rys. 9. Wagon systemu w odmianie $z$ oparciem na jednym czopie $\mathrm{z}$ każdej strony ramy

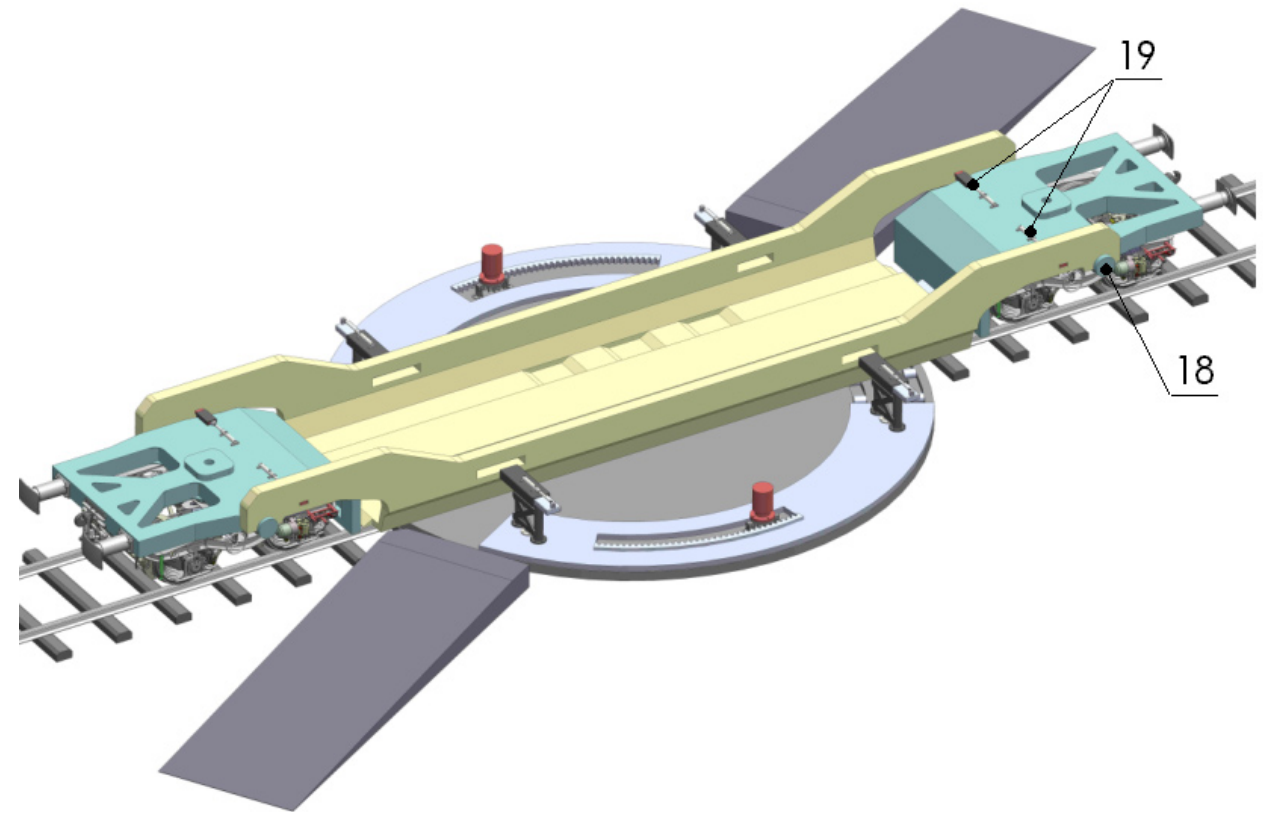




\subsection{Lifting and rotating mechanism}

Fig. 10 shows a top view of the rotation mechanism, consisting of the outer lower plates (item 20) and the inner bottom plate (item 21) placed between the track rails. Two upper plates (item 22) are supported on the bottom plates by means of radial rolling bearings (item 23). The upper plates are equipped with radial racks (item 24) with which the gears of hydraulic motors (item 25) attached to the bottom plates are meshed. Four hydraulic jacks (item 26) are placed on the upper plates, two on each plate.

Fig. 11 presents the jacks seen from the wagon front. The jack attached to the top plate is composed of a hydraulic cylinder (item 27) and guide columns (item 28) suitably stiffened with crossbars. A guide (item 29) with a sliding rectangular wedge placed in it, is attached to the inner columns. A hydraulic cylinder (item 30) with its piston rod connected to the wedge bracket, is fixed to the upper guide surface.

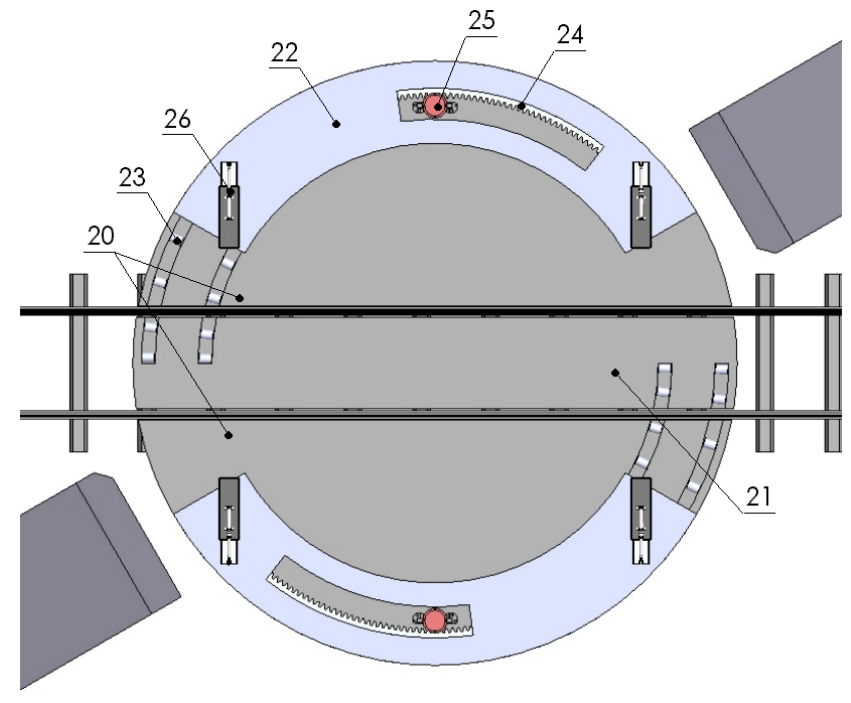

Fig.10. Top view of the rotation mechanism

Rys. 10. Mechanizm obrotu w rzucie z góry

In order to load and unload the semi-trailers the transshipment terminal should be provided with rotation mechanisms and ramps located next to each wagon. The train for transshipment of semi-trailers should be placed so as to align the rectangular openings existing in the walls of the basket sides with rectangular wedges of the jacks.

Figure 12a presents the operation of semi-trailer insertion into the basket with the help of a tractor unit, while Figure $12 \mathrm{~b}$ shows the trailer embedded in the basket, and the tractor driving down the ramp wedge.

\section{Summary}

In Poland, similarly to other European countries, the largest amount of goods shipped in intermodal transport is handled in container units. Nevertheless, the growth of use of standard road semitrailers for this purpose is observed. This situation results, among others from the fact, that the semi-

\subsection{Mechanizm podnoszenia i obrotu}

$\mathrm{Na}$ rysunku 10 przedstawiono w rzucie z góry mechanizm obrotu, który składa się z płyt dolnych zewnętrznych (poz. 20) oraz płyty dolnej wewnętrznej (poz. 21) umieszczonej miedzy szynami toru. Na płytach dolnych oparto dwie płyty górne (poz. 22) za pośrednictwem promieniowych łożysk tocznych (poz. 23). Płyty górne wyposażono w promieniowe zębatki (poz. 24), z którymi zazębione są koła zębate silników hydraulicznych (poz. 25) zamocowanych do płyt dolnych. Na płytach górnych ustawiono cztery podnośniki hydrauliczne (poz. 26), po dwa na każdej płycie.

$\mathrm{Na}$ rysunku 11 przedstawiono podnośniki w widoku od strony czoła wagonu. Podnośnik zamocowany do płyty górnej jest zbudowany z siłownika hydraulicznego (poz. 27) oraz kolumn prowadzących (poz. 28) odpowiednio usztywnionych poprzeczkami. Na wewnętrznych słupach kolumn zamocowano prowadnicę (poz. 29), w której umieszczono suwliwy klin prostokątny. Na górnej powierzchni prowadnicy zamocowano cylinder hydrauliczny (poz. 30), którego tłoczysko połączono ze wspornikiem klina.

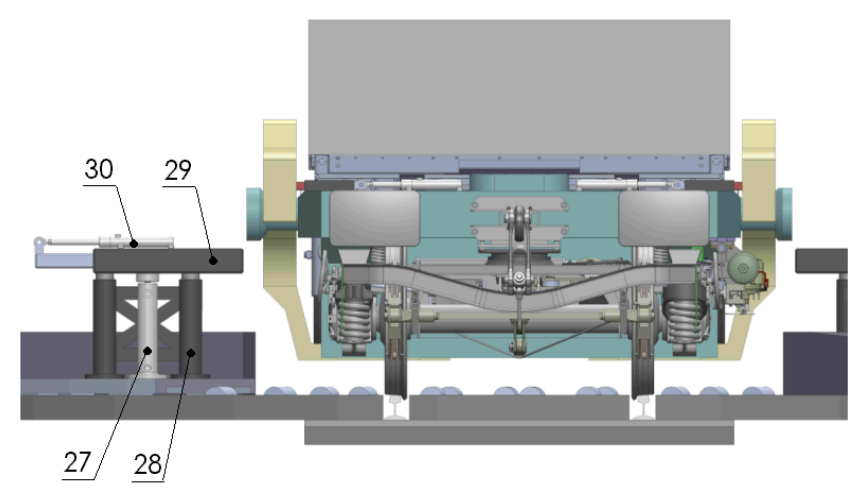

Fig.11. The jacks seen from the wagon front Rys. 11. Podnośniki w widoku od strony czoła wagonu

Do załadunku i wyładunku naczep należy terminal przeładunkowy wyposażyć w mechanizmy obrotu oraz pomosty najazdowe usytuowane przy każdym wagonie. Skład pociagu do przeładunku naczep należy ustawić tak, aby prostokątne kliny podnośników były ustawione naprzeciw prostokątnych otworów wykonanych w ścianach bocznych burt „kosza”. Rysunek 12a pokazuje wprowadzenie naczepy do kosza za pomoca ciagnika siodłowego, natomiast na rysunku $12 \mathrm{~b}$ przedstawiono osadzoną naczepę w koszu, oraz zjazd ciagnika po klinie najazdowym.

\section{Podsumowanie}

W Polsce $w$ transporcie intermodalnym podobnie jak $\mathrm{w}$ innych krajach europejskich najwięcej towarów przewożonych jest $\mathrm{w}$ jednostkach kontenerowych. Jednak zauważa się wzrost przewożonych towarów w standardowych naczepach drogowych. Sytuacja ta wynika m.in. z faktu, iż na drodze kołowej 


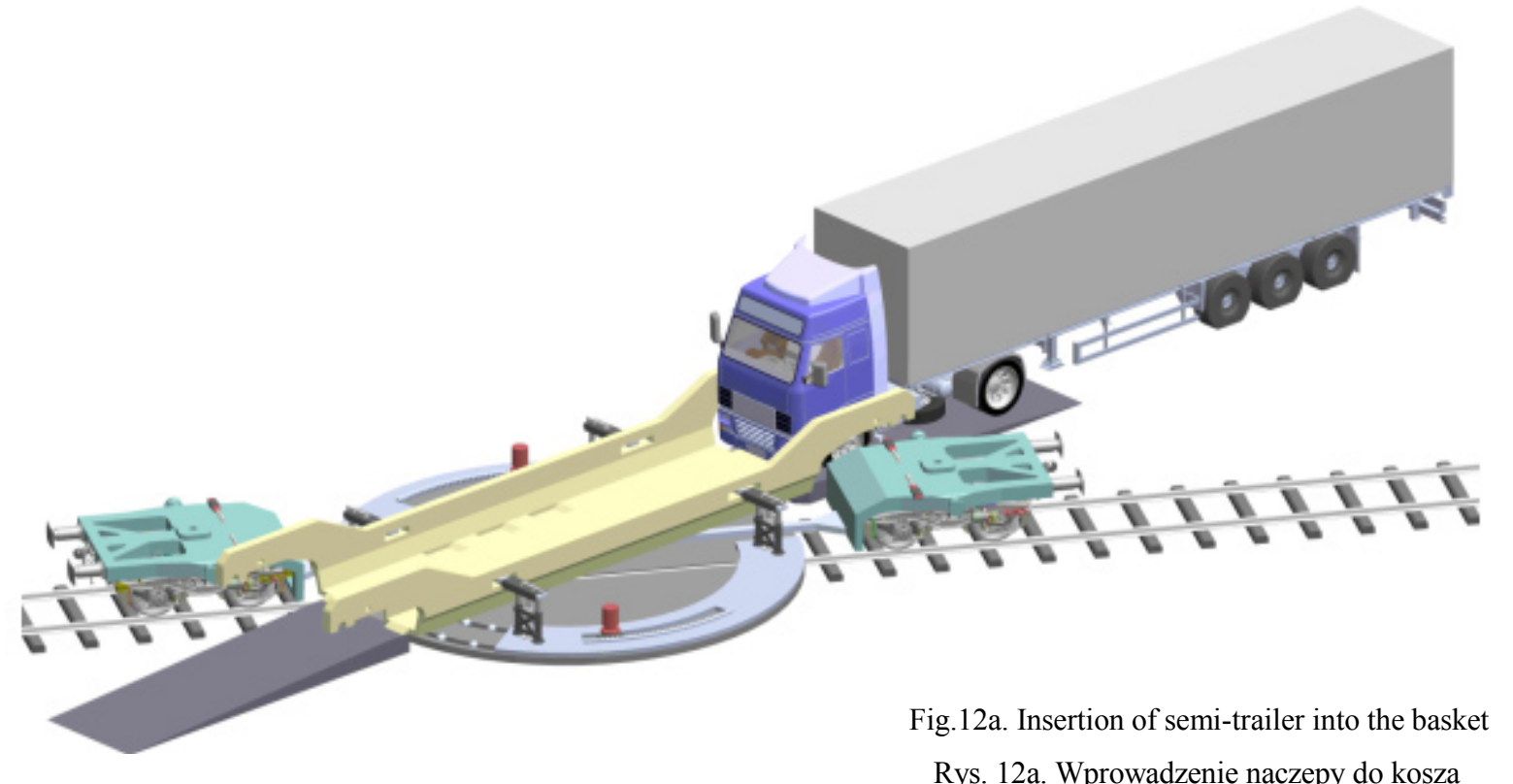

Rys. 12a. Wprowadzenie naczepy do kosza

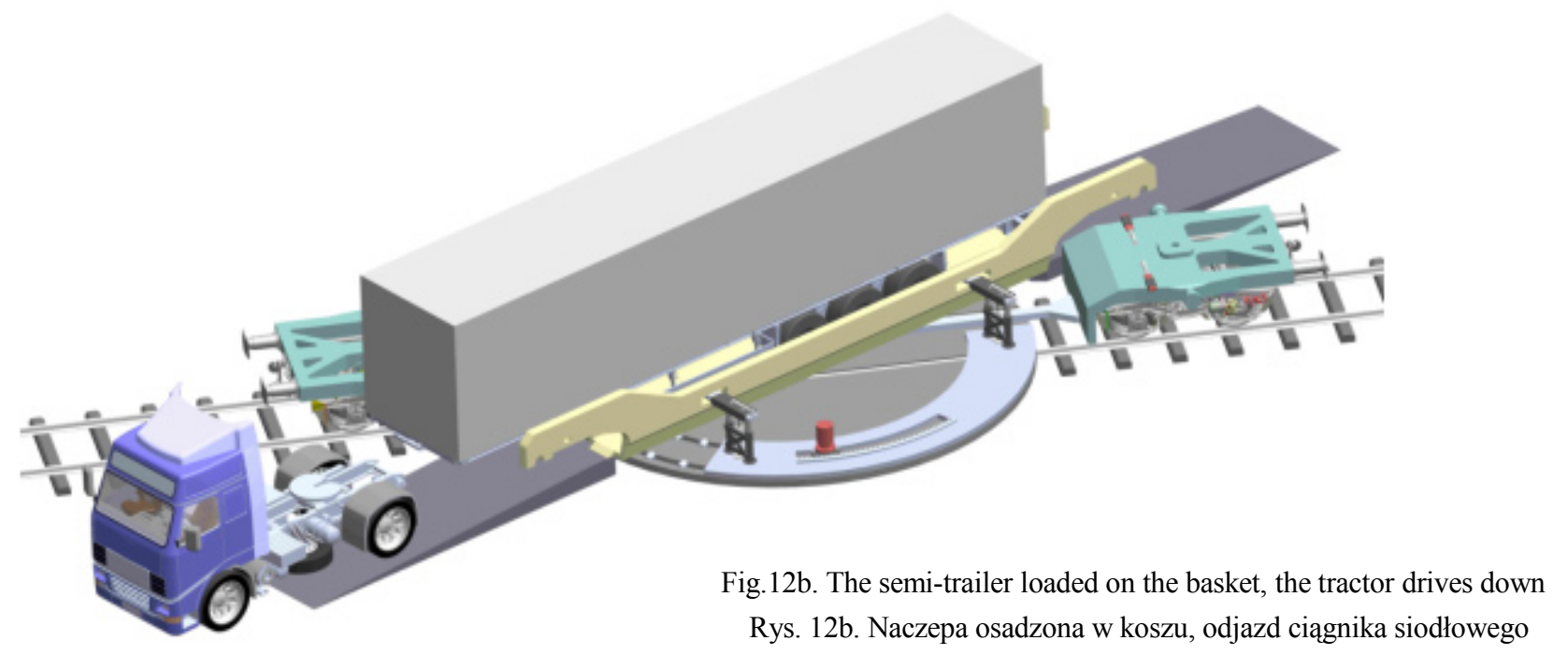

trailers are the most commonly used loading units on the roads. At present there are several systems in the world that allow transportation of road trailers. Several of them are in continuous use, the others, as e.g. Modalohr, are improved on an ongoing basis. In Poland, the largest number of well and pocket wagons is used to transport semi-trailers. In the world, especially in Europe, new concepts of intermodal systems are also developed. The designers make efforts to improve technical parameters such as rolling stock weight, length of the train, diameter of the railway wheels, railway gauge. Simplification of the loading methods is the designers' goal. It is often achieved by the use of the roll on - roll off system. Significant advantage of horizontal handling in intermodal transportation consists in possible use of electrified terminals, since the overhead contact line located at a height of approx. $5600 \mathrm{~mm}$ does not najczęściej wykorzystywaną jednostką ładunkową jest naczepa. Obecnie na świecie istnieje kilkanaście systemów umożliwiających przewóz naczep drogowych, kilka z nich jest $\mathrm{w}$ ciaggłej eksploatacji, niektóre są na bieżąco ulepszane jak np. system Modalohr. W Polsce do przewozu naczep drogowych wykorzystuje się najwięcej wagonów koszowych i kieszeniowych. $\mathrm{Na}$ świecie, szczególnie w Europie powstają także nowe koncepcje systemów intermodalnych. Konstruktorzy dążą do ulepszenia parametrów technicznych takich jak masa taboru, długość składu, średnica kół kolejowych, skrajnia kolejowa. Dąży się również do uproszczenia sposobu załadunku często poprzez stosowanie systemu roll on - roll of. Dużą zaletą przeładunku poziomego $\mathrm{w}$ transporcie intermodalnym jest możliwość zastosowania zelektryfikowanych terminali, gdyż sieć trakcyjna na wysokości ok. $5600 \mathrm{~mm}$ nie stanowi przeszkody podczas za- i wyładunku. W tym przypad- 
prevent the loading and unloading operation. The time saving results in this case from the fact that the electric locomotive can be used throughout the entire transport of goods on the rail road, also during reloading, without the need to couple a diesel shunter. An important advantage of the system can be a relatively low cost of technology and operation. The transportation technology should be based on the solutions requiring no frequent and costly service, at the same time the efforts should be made to minimize the out of operation time. Therefore, it is better to place the transshipment devices on the terminals than directly on the wagons. These devices can be serviced in the time between the reloading operations.

The present paper describes the systems designed for transporting road semi-trailers in combined traffic, used in Europe. A new concept of intermodal road trailer system is presented, distinguished by low rolling stock weight (the loading devices are located outside the wagon, they are of simple construction made of durable modern steel), horizontal loading (reduced handling time on terminals), system versatility and traffic safety (standard trolleys Y25), the upper UIC GB1 gauge and lower UIC 505-1 gauge. The presented reloading mechanism enables partially or fully automated reloading of the semitrailers. A disadvantage of the system is high cost of terminal construction compared to the well wagon, flexiwaggom or gutter wagon systems. The innovative system is characterized by simplicity of wagon construction and, hence, by higher reliability. Simplicity of the construction is directly related to lower production and operating costs as compared to previously presented foreign solutions. This concept has the above-mentioned advantages and is competitive to unimodal transport - road and the other intermodal systems. The design of the semi-trailer transportation system and their reloading have been submitted for patent protection in the Patent Office of the Republic of Poland.

\section{Bibliography / Literatura}

ku oszczędność czasu wynika z faktu, że lokomotywa elektryczna może być wykorzystana na całym etapie przewozów towarów po drodze szynowej, także podczas przeładunku, bez potrzeby załączania manewrowej lokomotywy spalinowej. Ważną zaletą systemu może być stosunkowo niski koszt pozyskania technologii oraz eksploatacji. Technologia transportu powinna opierać się na rozwiązaniach nie wymagających częstej i kosztownej obsługi, oraz aby jak najrzadziej wyłączać skład z ruchu. Dlatego lepszym rozwiązaniem jest zainstalowanie urządzeń przeładunkowych na terminalach niż bezpośrednio na wagonie. Urządzenia te mogą być obsługiwane w czasie między fazami przeładunkowymi.

W artykule opisano systemy do przewozu naczep drogowych w ruchu kombinowanym, stosowanych w Europie. Zaprezentowano nową koncepcję systemu intermodalnego do przewozu naczep drogowych, która charakteryzuje się niską masą taboru (brak urządzeń przeładunkowych na wagonie, prosta konstrukcja z wytrzymałych nowoczesnych stali), załadunkiem poziomym (skrócony czas obsługi na terminalach), uniwersalnością systemu i bezpieczeństwem ruchu (standardowe wózki Y25), górną skrajnią kolejową UIC GB1 oraz dolną UIC 505-1. Prezentowany mechanizm przeładunkowy pozwala na częściowy lub całkowicie zautomatyzowany proces przeładunku naczep.

Do wad systemu można zaliczyć wysoki koszt budowy terminali w porównaniu do systemów „wagon koszowy”, „flexiwaggon” lub „wagon rynnowy”. Innowacyjny system charakteryzuje się natomiast prostotą konstrukcji wagonu a co za tym idzie, wyższym poziomem niezawodności. $Z$ prostotą konstrukcji są bezpośrednio związane niższe koszty wytworzenia i eksploatacji w odniesieniu do wcześniej prezentowanych rozwiązań zagranicznych. Koncepcja ta posiada wyżej wymienione zalety, co powoduje jej konkurencyjność względem transportu unimodalnego - drogowego oraz pozostałych systemów intermodalnych.

Konstrukcja systemu przewozu naczep drogowych oraz ich przeładunku zostały zgłoszone do ochrony patentowej w Urzędzie Patentowym RP.

[1] Medwid M.,Cichy R.,Techniczne środki transportu kombinowanego kolejowo-drogowego, Instytut Pojazdów Szynowych „,TABOR”, Poznań 2017.

[2] Kwaśniowski S., Nowakowski T., Zajqc M., Transport intermodalny w sieciach logistycznych,Oficyna Wydawnicza Politechniki Wrocławskiej, Wrockaw 2008.

[3] Czerwiński J. Nowy system transportu kolejowo - drogowego dla przewozów standardowych naczep samochodowych, Rozprawa doktorska, 2017.

[4] Nowaczyk T.: Wybrane charakterystyki transportu intermodalnego (szynowo-drogowego), Praca magisterska NR TR-M/S-11/2009.

[5] Medwid M., Czerwiński J., Tomaszewski F., Nowaczyk T. Podanie o udzielenie patentu na wynalazek pt.: Stanowisko do załadunku i rozładunku naczep drogowych w systemie transportu kombinowanego kolejowo-drogowego oraz sposób załadunku i rozładunku naczep drogowych w systemie transportu kombinowanego kolejowo-drogowego. Instytut Pojazdów Szynowych „, TABOR”. Numer zgloszenia P.424899, 15.03.2018r. Urzad Patentowy Rzeczpospolitej Polskiej. 
[6] Medwid M., Czerwiński J., Tomaszewski F., Nowaczyk T. Podanie o udzielenie patentu na wynalazek pt.: Wagon, zwłaszcza do systemu transportu kombinowanego kolejowo-drogowego. Instytut Pojazdów Szynowych „,TABOR”. Numer zgłoszenia P.424900, 15.03.2018r. Urzqd Patentowy Rzeczpospolitej Polskiej.

[7] http://www.lohr.fr/gallery, luty 2018.

[8] http://www.cargobeamer.eu/how-it-works.html, luty 2018.

[9] http://www.flexiwaggon.se,luty2018.

[10] http://www.nagelgroup.com/en/danmark/kernekompetencer/intermodal_transport/intermodal_transport.html, luty $2018 r$.

[11] Archiwum Instytutu Pojazdów Szynowych „,TABOR”. 